\title{
IN SEARCH OF A THEORY FOR SUPPORTING RESISTANCE TO PREDATORY NEOLIBERALISM IN THE 21ST CENTURY
}

\author{
Suranjit Kumar Saha \\ Swansea University, United Kingdom
}

IN SEARCH OF A THEORY TO HELP THE RESISTANCE TO PREDATORY NEOLIBERALISM IN THE 21ST CENTURY

Abstract: This text deals with the search of fundamentals to the south-south research about the key-problems of the emerging configurations of a new and multipolar world order. Highlights two main questions: if the neoliberal orthodox in its various forms is to be effectively challenged and if the predatory policies resulting from it should be reverted. It starts of the perspective that is necessary an alternative paradigm of development, clearly enounced, which reinforces the national identity in Latin America, India and the rest of the world in development.

Such paradigm should favour the construction of mix and inclusives cultures able to create the sense of solidarity among great masses located in extensive areas with the objective to unblock, free and mobilize resistance against the predatory neoliberalism in the 21st century

Keywords: Neoliberalismo, resistance, national identity

EM BUSCA DE UMA TEORIA PARA AJUDAR A RESISTÊNCIA AO NEOLIBERALISMO PREDATÓRIO NO SÉCULO XXI

Resumo: O texto trata da busca de fundamentos para a pesquisa sul-sul sobre os problemas- chave das configurações emergentes de uma nova e multipolar ordem mundial. Destaca duas questões centrais : se o neoliberal ortodoxo em suas formas variadas é para ser efetivamente desafiado e se as políticas predatórias daí resultantes devem ser revertidas.Parte da perspectiva de que é necessário um paradigma alternativo de desenvolvimento, claramente enunciado, que reforce a identidade nacional na América Latina, Índia e o resto do mundo em desenvolvimento. Tal paradigma deve favorecer a construção de culturas mistas e inclusivas capazes de criar senso de solidariedade entre grandes massas situadas em extensas áreas com vista a desbloquear, libertar e mobilizar resistência contra o neoliberalismo predatório no século XXI Palavras-chave: Neoliberalismo, resistência, identidade nacional 
1 INTRODUÇÃO: what kind of future are we looking for and how do you get there?

What we are seeking here is a solid foundation for South-South research on the key issues of the emerging configurations of a new and, hopefully multipolar, global order. And if Stiglitz's belated concern about inequality, after a long innings at the World Bank, crafting precisely the policies which had been exacerbating those very inequalities, is any indication, at least a section of the social science fraternity of the capitalist centre, may be expected to begin raising doubts about the absolute veracity of the currently dominant neoliberal doctrine. If that happens, and if the researchers of the South, including those of Southern origin but based in the northern universities and institutions, can stay on course in focussing attention on the problem of increasing inequalities between and within countries, socially as well as spatially, and on the essentially predatory nature of the neoliberal doctrine, then and only then a real beginning could perhaps be made in rolling back those rampant forces which are currently ripping apart the very fabric of life for the vast majority of the world's population. Whether that majority is $99 \%$ or $90 \%$ or $80 \%$ or $70 \%$ may partly depend on the varying nuances of the figure of speech, partly on the varying shapes of the Gini-curves in different societies, partly on area specific ways classes and social categories are defined and the ways in which they interact with each other.

We also need to highlight the centrality of two tasks if the neoliberal orthodoxy in its various forms is to be challenged effectively and if the predatory policies stemming from it are to be rolled back. First is the creation of an alternative narrative of the history of global development from the perspective of the survivors of all forms of colonial oppression from the 15th century onwards, including genocides, mass slaughters, policy-engineered famines, forced migrations, planned impoverishments of large sections of populations, and grotesquely unequal relations of labour and trade sustained by coercive practices. This narrative needs to reflect the concrete experiences of successive generations of the peoples of Africa, Latin America and Asia from the 15th century onwards during the long histories of colonial expansion and consolidation by European powers. This narrative must capture not only the myriad forms of resistance mounted by the oppressed societies but alco the immensely complex dynamics of reconstitution, adjustment, accommodation that these societies went through because of the the violent contact with the forces of colonialism.

Only such a narrative can provide a solid foundation for an overarching alternative paradigm of development which is urgently needed to counter the debilitating effects of the currently dominant neoliberal orthodoxy. This orthodoxy, aided by its tendentious and prolific usages of complex econometric and statistical techniques, has this far successfully obfuscated and thus hidden the real dynamics and the nature of forces orchestrating the processes of impoverishment and deprivation from the gaze of the sufferers, the proverbial $99 \%$. By doing this, it has also drained the will, and prevented the organisation of resistance by this $99 \%$ against those predatory forces managed by a small but powerful minority.

Much of its power is derived from the ignorance of its victims about the real causes of their suffering. Only an alternative paradigm of development, clearly enunciated in plain and easy to understand language, can help remove this blindfold of ignorance from the eyes of the people, bringing to their clear gaze the line of causation which springs from the wilful actions of this minority. Once this happens, the power of this minority will rapidly turn into its vulnerability and fragility. This awareness will create the motivation and readiness in the rank's of the $99 \%$ to organise resistance against the forces of predation and a good chance for that resistance to be successful.

In this paper I only attend to this task perfunctorily because doing this well will take a lot more time and space than what is available while presenting a paper in the seminar. This first task, though important, is however only a precursor to the second task which is about putting intellectual power to the service of supporting resistance to neoliberalism, and help building solidarity of the $99 \%$ for achieving that purpose.

The second task, therefore, must involve putting the question of identities at the very heart of this new paradigm, i.e. posing the question who are we and what kind of future are we seeking? with regard to the question of national identity in Latin America, India and indeed in the rest of the developing world. The building of composite and inclusive cultures which can create a sense of solidarity among large masses of people over extensive areas and thus unblock, unleash and mobilise irrepressible energies of resistance against injustice and repression therefore has to be a critical part of this process.

\section{THE QUESTION OF INEQUALITY}

\subsection{Global contours of inequality}

In a paper published recently, Bourguignon and Morrisson has shown that inter-country income inequality across the world has been steadily rising from a level of 0.5 Gini coefficient in 1820 to around 0.66 in 1980 but has been slowly but steadily falling since then as a result of the global spread of industrialisation and technological development. This trend, however, says nothing about the longterm historical profiles of intra-country inequalities. 
In most countries for which data is available, however, intra-country inequalities declined from their peaks in the 1920 s to their lowest points in late 1970s and early 1980s and have been steadily rising again since then (BOURGUIGNON; MORRISSON, 2002). Between 1980 and 2010, intra-country income inequalities have risen in all the major economies with the exception of Brazil. It has risen by over $70 \%$ in the China and Russia, by over $20 \%$ in US, Germany, India, UK, Poland, Sweden, Finland, Czech Republic, Paraguay, Nigeria and New Zealand, and by lesser amounts in most of the rest of Europe, Japan, Indonesia, Australia, South Africa, Canada, Mexico, Argentina, Bolivia, Colombia, Ecuador, Guatemala and Honduras. It has fallen by $6 \%$ in Brazil, but the levels of inequality in all Latin American countries, including Brazil, have historically been, and continue to be much higher than almost anywhere else in the world; in fact so much higher that they are a different league altogether.

\subsection{Inequality in the US}

Ever since the stock market crash of 2008, inequality began to emerge as a major issue in the public consciousness and policy circles in the US, as indeed in much of the rest of the world. Joseph

Table 1 - Contours of inequalities in the world's major economies

\begin{tabular}{|c|c|c|c|c|c|c|c|c|}
\hline Countries & $\begin{array}{l}\text { No. of } \\
\text { billionaires } \\
\text { in } 2013^{1}\end{array}$ & $\begin{array}{l}\% \text { of GDP } \\
\text { owned } \\
\text { by the } \\
\text { billionaires }{ }^{1}\end{array}$ & $\begin{array}{l}\text { Gini in } \\
1980 \text { or } \\
\text { nearest } \\
\text { year }^{2}\end{array}$ & $\begin{array}{l}\text { Gini in } \\
2010 \text { or } \\
\text { latest year }{ }^{2}\end{array}$ & $\begin{array}{l}\text { \% rise/ } \\
\text { fall in } \\
\text { inequality } \\
\text { between } \\
1980 \text { and } \\
2010\end{array}$ & $\begin{array}{l}\text { GDP share } \\
\text { of the } \\
\text { poorest } \\
10 \%^{3}\end{array}$ & $\begin{array}{l}\text { GDP } \\
\text { share of } \\
\text { the richest } \\
10 \%^{3}\end{array}$ & $\begin{array}{l}\text { Income gap } \\
\text { between } 10 \% \\
\text { richest and } \\
10 \% \text { poorest } \\
\text { (multiples) }\end{array}$ \\
\hline US & 442 & 10.5 & 0.301 & 0.386 & 28.2 & 1.9 & 29.9 & 15.7 \\
\hline China & 122 & 2.6 & 0.234 & 0.415 & 77.4 & 1.8 & 32.0 & 17.8 \\
\hline Russia & 110 & 18.6 & 0.251 & 0.451 & 79.7 & 2.8 & 31.7 & 11.3 \\
\hline Germany & 58 & 7.2 & 0.244 & 0.321 & 31.6 & 3.2 & 22.1 & 6.9 \\
\hline India & 55 & 10.9 & 0.314 & 0.394 & 25.5 & 3.8 & 28.3 & 7.4 \\
\hline Brazil & 46 & 6.2 & 0.553 & 0.520 & -6.0 & 0.8 & 42.9 & 53.6 \\
\hline UK & 37 & 4.0 & 0.270 & 0.335 & 24.1 & 2.1 & 28.5 & 13.6 \\
\hline Japan & 22 & 1.3 & 0.300 & 0.329 & 9.7 & 4.8 & 21.7 & 4.5 \\
\hline
\end{tabular}

Sources: Forbes (2013), Bastagli, Coady and Gupta (2012) and UNDP (2012).

Stiglitz's recent book on inequality is focused almost entirely on the nature and causes of deepening inequality in the US, particularly since the crisis of 1998. It shows that the so-called success story of the capitalist democracy is after all not a success story at all and the much celebrated American dream is in fact fast turning into an American nightmare for its poor and middle classes. The book's point of departure is this:

In America the share of national income going to the top $.01 \%$ (some 16,000 families) has risen from just over $1 \%$ in 1980 to almost $5 \%$ now [...] that in the period of recession, from 2007 to 2010 , median wealth - the wealth of those in the middle fell by almost 40 percent $[\ldots]$ [and] All the wealth accumulation in this country has gone to the top. (STIGLITZ, 2013, p. 11-12).

In much of the book, he draws on various sources to present a whole lot of facts to highlight the extent and enormity of growing inequality in the US society. In 2007, the average income of the richest $0.1 \%$ was 220 times higher than the average of the poorest $90 \%$, up from only around $50 \%$ in 1979 . During the same period, the average income of the richest
$1 \%$ increased from 14 times to 42 times, relative to the average for the poorest $90 \%$ (STIGLITZ, 2013). The wealth gap between the two groups also widened from 131 times in 1983 to 225 times in 2007. Of the total stock of wealth arising out of capital gain between 1979 and $2007,88 \%$ had accrued to the top $1 \%, 9 \%$ to those between the top $2 \%$ and $4 \%$, and only $3 \%$ to the bottom 95\% (STIGLITZ, 2013).

The fundamental malaise was this: America's concentration of wealth at the top was a result of rent seeking - including monopoly profits, and not, as is often touted by the apologists of neoliberal capitalist, created as fruits of enterprise and hard work. As regards the often repeated suggestion that the problem will be resolved eventually by the markets, his response is very clear:

[...] markets don't exist in a vacuum. They are shaped by our politics, often in ways that benefit those at the top. (STIGLITZ, 2013, p. 14-15).

He argues that the US is currently trapped in a two-strand mutually interlocking and reinforcing mechanism, both of which stem from deeply entrenched economic inequalities in the society. This is how it works: 
[...] societies with more economic inequality tend to have more political inequality, especially when it reaches the outside levels found in the United States and a few other countries. And with a political system that allows the rich to exercise so much influence, it's perhaps no surprise that taxes on the rich are as low as they are. [...] (also) much of the inequality, especially at the top, is related to rent seeking. Rent seeking is, on average, destructive [...] (STIGLITZ, 2013, p. 33).

The language he uses in some places of the book seems like the language of the radical left. He alleges that the US macroeconomic policy and its Central Bank look like designed "[...] by and for the 1 percent [...]" (STIGLITZ, 2013, p. 298) and suggests that the US may have

[...] become like one of these disturbed places (e.g. Egypt, Tunisia, Libya, Yemen, Syria and Bahrain), serving the interests of a tiny elite. (STIGLITZ, 2013, p. 360).

Where governments are toppled or seriously challenged by street uprisings or civil wars.

Stiglitz is indignant about the current state of inequality and injustice in the US; to him it represents a moral degradation.

Something wrong happened to the moral compass of so many of the people working in the financial sector and elsewhere. [...] Capitalism seems to have changed the people who were ensnared by it. [...] [It] is failing to produce what was promised, but is delivering on what was not promised inequality, pollution, unemployment, and most important of all, the degradation of values to the point where everything is acceptable and no one is accountable. (STIGLITZ, 2013, p. 47).

These are brave and radical words. But the way forward he suggests, comprising an economic reform agenda and a political reform agenda, will not even begin to replace the present system with another capable of promoting equality, fairness and fair play, the three fundamental values espoused by him or "[...] ensuring that the political process is more responsive to the concerns of the 99 percent." (STIGLITZ, 2013, p. 358). The two agenda's have no teeth. They can be implemented only if the richest $1 \%$ can be made to realise that their fate, in the long term, is tied up with a better deal for the other $99 \%$. But why should a class of people so securely entrenched in a political system and in its institutions geared to delivering to it a lion's share of incomes and wealth that the economy produces, ever want to understand any such thing? Only a credible challenge to its privileged position in the institutions of economic and political power mounted by a credible mobilisation of the $99 \%$ organised and spearheaded by a strong and well-structured leadership of the masses can make it feel insecure and countenance change. Stiglitz does not say how the $99 \%$ will mount this challenge.

He presents the frightful vision of a classdivided society in which the haves live in secure gated communities with access to all good things in life, living side by side with the have-nots who live in insecurity, only limited access to education and healthcare and in hopelessness. If nothing changes, this nightmare will become a reality in the US in fifty years, he says. But he is wrong; this nightmare is already staring the US and the rest of the developed world in the face. The $1 \%$ do not seem to mind it and are ready to live with it. The $99 \%$ do not yet know how to get out of it; nor does Stiglitz tell them how. They have to look elsewhere to find a roadmap.

Stiglitz may not have suggested a credible way out of the present nightmare of hopelessness that the poorer majorities find themselves in across the world, but the fact that a former functionary of the World Bank and a former chief economic advisor to President Clinton is now telling the $99 \%$ of the world so convincingly that the capitalist system and the democracies powered by it have nothing to offer them except more of the same or even worse, is a harbinger of hope in itself. It helps in dispelling the myth that the ills of the present day capitalist democracies can be fixed by patchwork repairs. Without dispelling this myth completely, a serious quest for a new system, and a mobilisation of the people towards achieving it, cannot begin.

\subsection{Inequality in the UK}

Towards the very end of its 13 year long tenure in office (1997 to 2010) UK's Labour Government appointed a National Inequality Panel in September 2008 which published its report in January 2010, known widely as the Hills Report (GOVERNMENT INEQUALITIES OFFICE, 2010a). It discovered that the hourly wages earned by the top $1 \%$ of the employees were 17 times higher than those received by the bottom $1 \%$ and 4.3 times higher than the medium and that the magnitude of these inequalities have become considerably worse over the generation, i.e. since 1961. Inequalities had started to rise particularly since 1979 (GOVERNMENT INEQUALITIES OFFICE, 2010a), which is when Margaret Thatcher took office as the Prime Minister. It further discovered that in the matter of income inequality, UK's position was among the worst in Europe ( $4^{\text {th }}$ in a list of 22 European countries; only Portugal, Poland and Italy figured even worse than the UK) (GOVERNMENT INEQUALITIES OFFICE, 2010a). 
The British newspaper Guardian had produced a detailed analysis of the data presented in the Hills Report. It showed that the poorest $1 \%$ in Britain received an income of $£ 5,668$ annually, whereas the richest $99^{\text {th }}$ percentile received $£ 99,360$ or 77.5 times more. As for the top $1 \%$, it simply said that sky is the limit, but provided the example of Stephen Hester, the chief executive of the RBS bank who received an annual income of $£ 1.2$ million. The gap between the poorest and the richest in life-time net worth is even greater. The poorest $1 \%$ had an average negative net worth of $£-3,844$ and the second percentile a net worth of $£ 1,421$, whereas the richest $99^{\text {th }}$ percentile had an average net worth of $£ 2,574,327$. The net worth of the $99^{\text {th }}$ percentile was thus 1822 times greater than the net worth of the $2^{\text {nd }}$ percentile. With regard to the top $1 \%$, the sky, again, was the limit (SCRUTON et al, 2010). It was against this background of mammoth disparities that the report had provided this sombre conclusion:

Much of what we have described in this report shows the way economic advantages and disadvantages reinforce themselves across the life cycle, and often on to the next generation. [...] intergenerational mobility appears lower in societies such as ours which are more unequal. A fundamental aim of those people with differing political perspectives is to achieve 'equality of opportunity', but doing so is very hard when there are such wide differences in resources which people and their families have to help them develop their talents and fulfil their diverse potentials. (SCRUTON et al, 2010, p. 403).

The report had stressed the centrality of greater "[...] progressivity of the tax system and the level of social security benefits and tax credits." if a policy were to seek to address this kind of inequality (SCRUTON et al, 2010). The Labour Government got defeated shortly after the publication of this report in the general election of May 2010. But there is very little evidence to suggest that it would have really done anything significant to deal any thing significant to deal with this growing inequality in the British society or if it indeed would have seen it as a problem. The current Conservative Party-led government will certainly not do anything about it.

A second report on poverty and inequality in the UK was also published in the same year by the influential and prestigious independent think tank, Institute for Fiscal Studies (INSTITUTE FOR FISCAL STUDIES, 2010a), which used the same sources of data as the UK government report did. Its analysis focused on the period 1979 to 2009, which roughly corresponded with the three successive Conservative Party governments (1979 to 1997) followed by the three successive Labour Party ones
(1997 to 2010). It found that during the 18 years of Conservative rule, the annual average income of the richest quintile rose by $2.5 \%$ and that of the poorest quintile, by only $0.8 \%$, i.e. the former grew three times faster. During the Thatcher period (1979 to 1990), the gap was even bigger - the growth rate of the richest quintile was $3.6 \%$ and that of the poorest, $0.4 \%$, i.e. the income of the richest grew nine times faster than the poorest. The performances of the three Labour governments were mixed. During the first two Labour governments (1997 to 2005), the incomes of the poorest quintile rose much faster than they did during the preceding Conservative governments, but during the third Labour government, the incomes of that quintile actually fell. During the three Labour governments taken together, the average annual incomes of the richest quintile still grew faster than the poorest quintile; $1.8 \%$ against $1.6 \%$ (INSTITUTE FOR FISCAL STUDIES, 2010a). Looking at the historic trend of inequality, the report also found that the overall inequality had shot up from during the Thatcher government, from a Gini coefficient figure of 0.25 in 1979 to 0.33 in 1990, fell slightly during the early part of the Major period but rose again to 0.33 by the fall of that government in 1997. The inequality kept rising under Tony Blair's Labour Government too and stood at 0.36 in 2008 (INSTITUTE FOR FISCAL STUDIES, 2010a). During the period of the three Labour Governments between 1997 to 2010, however, the absolute poverty, defined on the basis of a poverty line fixed in real terms at $60 \%$ of 1996 97 median income, after accounting for housing cost, had decreased from $25.3 \%$ to $13.6 \%$ (INSTITUTE FOR FISCAL STUDIES, 2010a). Neither of the two major political parties in Britain thus seemed committed to seriously addressing the issue of inequality, but Labour did seem to make efforts to roll back absolute poverty.

Shortly after assuming office in May 2010, the new Conservative-led government had announced in its budget sweeping changes in the country's tax and benefit structure which it claimed to be progressive (GOVERNMENT INEQUALITIES OFFICE, 2010b). However, a detailed analysis of these changes undertaken by the IFS (2010b, p. 1 e 6) clearly established that

[...] the overall effect of the new reforms announced in the June 2010 Budget is regressive, whereas the tax and benefit reforms announced by the previous Government for introduction between June 2010 and April 2014 are progressive.

During the 2010-2014 period these reforms are designed to further reduce the incomes of the poorest $60 \%$ households and further increase the incomes of the richer $40 \%$; the poorest quintile will be hurt the most. The present Conservative-led 
government is thus on course to reverse even the modest gains made during the previous three Labour governments in ameliorating absolute poverty.

\subsection{Inequality in Latin America}

Inequality in Latin America has always been higher than the rest of the world. In 1980, the Gini figure for Argentina was 0.376 , which was remarkably low for Latin America but still much higher than all the countries of Europe and North America. From then onwards it rose constantly for the next twenty years, reaching a peak of 0.483 in 0.483 , from which point it started declining, reaching 0.42 in 2010 . In Brazil, inequality has always been much higher than Argentina, and indeed than all the rest of Latin America and the world. Its peak at 0.588 was in 1990 and remained around that figure until 2000, since when it declined somewhat until reaching 0.52 in 2010 . Even after this decline, inequality in Brazil is still much higher than in Argentina, Chile, Costa Rica, Ecuador, El Salvador, Guatemala, Nicaragua, Panama, Paraguay, Peru, Uruguay and Venezuela. In 2010; only Bolivia, Colombia, Haiti,

Table 2 - Contours of inequalities in Latin America

\begin{tabular}{|c|c|c|c|c|c|c|c|c|}
\hline Countries & $\begin{array}{l}\text { No. of } \\
\text { billionaires } \\
\text { in } 2013^{1}\end{array}$ & $\begin{array}{l}\% \text { of GDP } \\
\text { owned } \\
\text { by the } \\
\text { billionaires }{ }^{1}\end{array}$ & $\begin{array}{l}\text { Gini in } \\
1990 \text { or } \\
\text { nearest } \\
\text { year }^{2}\end{array}$ & $\begin{array}{l}\text { Gini in } \\
2010 \text { or } \\
\text { latest year }{ }^{2}\end{array}$ & $\begin{array}{l}\text { \% rise/ } \\
\text { fall in } \\
\text { inequality } \\
\text { between } \\
1990 \text { and } \\
2010\end{array}$ & $\begin{array}{l}\text { GDP share } \\
\text { of the } \\
\text { poorest } \\
10 \% \text { in } \\
2010^{3}\end{array}$ & $\begin{array}{l}\text { GDP } \\
\text { share of } \\
\text { the richest } \\
10 \% \text { in } \\
2010^{3}\end{array}$ & $\begin{array}{l}\text { Richest to } \\
\text { Poorest } \\
\text { gap in } \\
2010\end{array}$ \\
\hline Brazil & 46 & 7.7 & 0.588 & 0.520 & -11.6 & 0.8 & 42.9 & 53.6 \\
\hline Mexico & 15 & 11.5 & 0.511 & 0.516 & 1.0 & 1.4 & 37.2 & 26.6 \\
\hline Chile & 14 & 17.9 & 0.537 & 0.506 & -5.8 & 1.5 & 42.8 & 28.5 \\
\hline Peru & 10 & 10.6 & 0.514 & 0.468 & -8.9 & 1.4 & 36.1 & 25.8 \\
\hline Colombia & 5 & 8.6 & 0.483 & 0.558 & 15.5 & 0.9 & 44.4 & 49.3 \\
\hline Argentina & 5 & 2.2 & 0.442 & 0.422 & -4.5 & 1.5 & 32.3 & 21.5 \\
\hline Venezuela & 3 & 2.8 & 0.399 & 0.412 & 3.3 & 1.2 & 33.2 & 27.7 \\
\hline Uruguay & & & 0.404 & 0.423 & 4.7 & 1.9 & 34.4 & 18.1 \\
\hline Paraguay & & & 0.393 & 0.489 & 24.4 & 1.0 & 41.1 & 41.1 \\
\hline Ecuador & & & 0.573 & 0.467 & -18.5 & 1.4 & 38.3 & 27.4 \\
\hline Bolivia & & & 0.509 & 0.551 & 8.3 & 0.5 & 43.3 & 86.6 \\
\hline Nicaragua & & & 0.543 & 0.500 & -7.9 & 2.6 & 31.5 & 12.1 \\
\hline Panama & & & 0.535 & 0.495 & -7.5 & 1.1 & 40.1 & 36.5 \\
\hline El Salvador & & & 0.505 & 0.446 & -11.7 & 1.0 & 37.0 & 37.0 \\
\hline Costa Rica & & & 0.422 & 0.485 & 14.9 & 1.2 & 39.5 & 32.9 \\
\hline Honduras & & & 0.494 & 0.538 & 8.9 & 0.4 & 42.4 & 106.0 \\
\hline
\end{tabular}

Sources: Forbes (2013), Bastagli, Coady and Gupta (2012) and UNDP (2012).

Honduras and Jamaica were more unequal societies than Brazil. Argentina, Uruguay and Venezuela are the most equal societies in the continent, but even these are much more unequal than the developed countries and most of Asia (BASTAGLI; COADY; GUPTA, 2012).

\section{DEFENDING THE RICH}

As the tide of consciousness was spreading across the world about the predatory nature of neoliberal capitalism and about the fact that unregulated market forces necessarily generate increasing levels of inequality, which in turn produces mass poverty and misery, the defenders of this defunct system also started gathering force to capture the high moral ground of the public opinion space. Janet Daley writing in Sunday Telegraph exhorted the Tory supporters to make it clear that capitalism contain
[...] the vices of human beings (like) greed, selfishness and dishonesty, but also the virtues (of) creativity, industriousness and courage (and) provides all the wealth that there is for public services and government funding. (DALEY, 2010).

All arguments against free market economics are just "[...]cheap, hysterical taunts [...]" and take the form of a "[...] relentless torrent of pointless abuse [...]" hurled against "[...] capitalism, the banks and speculators [...]", none of which will "[...] stand up to a moments examination [...]" (Daley, 2010). Making the case for capitalism should have seemed a bit like a foolhardy rant at a time when papers were reporting that 2,800 bankers, precisely the people who had triggered the economic crisis in 2008, were taking home more than a million pounds each in bonuses, when the Lloyds chief, Eric Daniels was awarded $£ 2.3$ million in bonus on top of his $£ 1.1$ million salary 
and when the poorest $60 \%$ of the British people were getting even poorer because of the deliberately designed pro-rich policies of the Conservative-led government, figures cited in Treanor (2011). But that did not deter the defenders of the system.

The Economist, the widely respected British weekly which is regarded as the principal reasoned voice of capitalism in the country, published a special report in defence of the rich in April 2009 (THE ECONOMIST, 2009a). In this report, it picked up the two terms deserving and undeserving rich earlier used in an article by Prasad et al (2009). They were addressing the question why the white working class in the US voted for Bush in overwhelming numbers despite his known pro-rich policies and the answer they found was the following:

Wealth, in and of itself, does not threaten a candidacy. But "undeserved" wealth does. Our respondents perceived Bush as part of the "deserving rich"- those whose mannerisms suggest that they are able to see the true human worth of everyone-while they saw Kerry as part of the "undeserving rich"-those who believe their elevated social position makes them superior to others, or who see money as an end in itself. (PRASAD et al, 2009, p. 251).

The Economist believed that ordinary people made the distinction in a different way. The deserving rich were the entrepreneurs, those who set up big companies like Microsoft and Apple, the undeserving ones were the traders, brokers and fund managers of the financial sector. But it strives to make the case that neither really merits the term undeserving and that neither should be taxed or financially penalised in a hurry and it warns:

Squeeze the rich until the pips squeak, and the juice goes out of the economy. [...] The rich are the easy target. But when you punch them, you usually end up punching yourself in the nose. (THE ECONOMIST, 2009b, p. 11).

In 2011, The Economist (2011a; 2011b) publishes another report on the rich who it calls global leaders. It offers various arguments to assuage ordinary people's growing revulsion against the widening inequalities between the rich and the poor. To some extent growing inequality is inevitable because "Modern technology favours the skilled (and) educated men now tend to marry educated women." (THE ECONOMIST, 2011a, p. 11). It provides data to show that disparities are indeed galling.

The richest $1 \%$ of adults control $43 \%$ of the world's assets; the wealthiest $10 \%$ have $83 \%[\ldots]$ giving them a lot of say in funding businesses, charities and politicians. (THE ECONOMIST, 2011b, p. 6-7).

And yet it argues that inequality should not jar us because in most cases "[...] the rich have earned their fortunes [...]" and because "[...] talents are rewarded [...]" (THE ECONOMIST, 2011b, pp. 8-9). After all capitalist democracies provide opportunities to people of humble backgrounds like Barack Obama to rise to the top. In these democracies: "Cash seldom buys political power. What counts are ideas and the ability to inspire." and this the rich are in the best position to provide and do (THE ECONOMIST, 2011b, p. 10-12). The elites, no matter how rich, serve the masses. It goes to great lengths in seeking to dismiss Wilkinson and Pickett's (2009) thesis that more equal countries fare better on a whole range of economic and social indicators. The report's recommendation for dealing with inequality is this: "[...] governments need to keep their focus on pushing up the bottom and middle rather than dragging down the top." (THE ECONOMIST, 2011a, p. 12). In other words, do whatever you can, but do not touch the wealth of the rich.

In October 2012, The Economist published a third report on the state of inequalities in the world which too presented a case for not hurting the interests of the rich too much, but this time in a much more nuanced way:

[...] some measure of inequality is good for the economy. It sharpens incentives to work hard and take risks; it rewards the talented innovators who drive economic progress [...] (but now) inequality has reached a stage where it can be inefficient and bad for growth. (THE ECONOMIST, 2012a, p. 13).

Because (big income gaps)

[...] can bar talented poor people from access to education or feed resentment that results in growth-destroying populist policies. (THE ECONOMIST, 2012b, p. 4).

It warns:

Too often high-tax welfare states turned out to be inefficient and unsustainable. Government cures for inequality have sometimes been worse than the disease itself. (THE ECONOMIST, 2012b, p. 6).

The three-strand strategy it recommends to deal with the problem of inequality across the world also seeks to protect the interests of the rich, particularly the 'deserving' rich. The three strands ate: (i) greater transparency in the government to deal with crony capitalism, (ii) more targeted welfare spending (iii) tax reforms which do not "[...] punish the rich but 
raise money more efficiently and progressively." (THE ECONOMIST, 2012a, p. 13-14). It approvingly quotes from the Nobel-prize winning neoliberal economist Robert Lucas Jr. (2003, p.12) who had said:

Of the tendencies that are harmful to sound economics, the most seductive, and in my opinion the most poisonous, is to focus on questions of distribution.

The ferocity of the right's counterattack must not be underestimated, the nature of which Monibiot (2013, p. 26) states so eloquently:

It is no longer enough to own the land and most of the capital, to own the media and - through the corrupt system of party funding - the political process. To reinstate Edwardian levels of inequality, the feral elite must seek to reverse the political progress that has been made since then. This means dismantling the tax system, which redistributes wealth. It means ditching the rules that prevent the powerful from acting as they please. [...] This conservatism does not care whom it hurts. It will not [...] contemplate the slightest check on its own self interest. All else can burn.

\section{THE QUESTION OF IDENTITY}

As the Irish political scientist Benedict Anderson (1983, p. 15) has argued in his widely read book Imagined Communities, a nation is always an imagined community and not a primordial or an eternally constructed entity.

\begin{abstract}
I propose the following definition of the nation: it is an imagined political community - and imagined as both inherently limited and sovereign. [...] In fact, all communities larger than primordial villages $\ldots$ are imagined. Communities are to be distinguished, not by their falsity/genuineness, but by style in which they are imagined.
\end{abstract}

The Czech philosopher, Ernest Gellner (1964, p. 169) had also defined the concept of national identity in similar terms: "Nationalism is not the awakening of nations to self-consciousness: it invents nations where they do not exist".

Anderson traces the origin of nationalism to the two medieval cultural systems of religious community and the dynastic realm. He identifies three religious communities - Christendom, Islam and the Han Chinese Middle Kingdom, glued together respectively by the three classical languages of Latin, Arabic and the Han Chinese ideographs. Interestingly, he fails to include the evolution of the Hindu religious system cemented over an extensive territory by the common language of classical Sanskrit, which according to a whole range of Indian historians of the left, including Kosambi, Thapar and Sharma, had provided the basis of the Indian national consciousness in preChristian times. After the gradual decline of the religious influence over the masses, particularly post-Renaissance, the dynastic realms like the House of Hapsburg and the Bourbons provided points of reference for imagining identities in Europe. In India, the dynastic realms like the Mauryas (332 BC-185 BC) and the Guptas (320 AD - 554 AD) would have played the same role, but this would extend the historical timescale of the emergence and maturation of similar processes there several centuries before they happened in Europe. With the rise of what Anderson (1983) calls print-capitalism in Europe in the 16th century and as "By the 17 th century languages in Europe had generally assumed their modern form." (FEBVRE; MARTIN, 1958 , p. 477), the old solidarities tied to religious or dynastic consciousness began to fragment into a larger number of newer national identities based on these modern languages, standardised by the print media. This language-based ethnicity continues to be the rubric of European nationalism to this day.

The key is the way this imagination or invention is done and the historical context in which it is done. As is often the case:

\section{[...] it is imagined as a community, because, regardless of the actual inequality and exploitation that may prevail in each, the nation is always conceived as a deep, horizontal comradeship. Ultimately it is this fraternity that makes it possible, over the past two centuries, for so many millions of people, not so much to kill, as willingly to die for such limited imaginings. (ANDERSON, 1983, p. 16, emphasis added).}

This is where the problem lies in the imagination of nationalism crafted by the dominant classes. Imagined in this way a 'nation' becomes a fraternity which bonds together the dominant classes and the exploited masses within a territorial unit in a shared consciousness of solidarity. This kind of consciousness filters out the awareness of deep divisions of interest between the two sides of society, those who exploit and those who are exploited, which exists in each capitalist society, as indeed existed in pre-capitalist societies as well. Once this false idea of solidarity takes roots in the minds of the exploited, the dominant classes find it easy to mobilise the masses, and use them as cannon fodder, in wars of aggression against other nations. In such wars, no matter which side wins, it is always the dominant class which appropriates the lion's share of the gains, while the masses of both sides absorb the lion's share of the cost of war, including casualties and deprivations. 
But the progressive scholars anywhere, particularly in developing countries, must not let the dominant classes get away with imagining national identity in this way. Scottish political scientist Tom Nairn (1977, p. 41) points to this alternative way of constructing this concept:

The arrival of nationalism in a distinctively modern sense was tied to the political baptism of the lower classes [...] nationalist movements have been invariably populist in outlook and sought to induct lower classes into political life. In its most typical version, this assumed the shape of a restless middle-class and intellectual leadership trying to stir up and channel popular class energies into support for the new states.

Engels, in a letter written to Karl Kautsky on 7 February 1882 had this to say about the primacy of national independence for the building of socialism:

One of the real tasks of the Revolution of 1848 [...] was the constitution of the suppressed and scattered nationalities of Central Europe, provided they were at all viable and provided especially that they were ripe for independence. This task was accomplished by the executors of the revolution, Bonaparte, Cavour and Bismarck for Italy, Hungary and Germany in accordance with the then prevailing conditions. [...] It is historically impossible for a great people even to discuss internal problems of any kind seriously, as long as it lacks national independence. [...] An international movement of the proletariat is possible only among independent nations. [...] So long as Poland is partitioned and subjugated, therefore, neither a strong socialist party can develop in the country itself, nor can there arise real international intercourse between the proletarian parties in Germany, etc, with other than émigré Poles. (KAUTSKY, 1935).

Nationalism of the masses is thus a very different thing than the nationalism of the elite. But unlike Nairn, nationalism of the masses can also be constructed as an instrument of mobilising them across the boundaries of the existing states for creating larger geographical units of solidarity rather than breaking up the existing states into smaller fragments on narrow, ethnic, linguistic, racial, religious or sectarian lines. In the context of the contemporary world, and particularly contemporary Latin America, Engel's perception of nationalism seems to be better suited for playing the latter role than the former one. What I am arguing here is for supporting popular movements for trans-state solidarities of the working classes across large geographical areas like Latin America for fighting the oppressive policies emanating from the core of neoliberal capitalism.

\section{WHICH THEORIES?}

\subsection{Liberation theology}

Catholic Church in Latin America has built up a hallowed tradition of actively fighting for the rights of the oppressed and marginalised in society. It has done so by not only reinterpreting Christian theology as a moral force for providing support to struggles of resistance against the forces of oppression including the state, but also by its clergy standing shoulder to shoulder with the most deprived and marginalised sections of people in their struggles to secure their rights, often carrying huge risks of death at the hands of the oppressors.

The Vatican itself had provided legitimacy and doctrinaire support to this radical role of the Church by the presentation by Pope Paul VI of his encyclical Populorum Progressio at the Second Vatican Council on March 26, 1967. In this document, Pope Paul VI characterises as less than human conditions the unacceptable contradiction between

[...] the material poverty of those who lack the bare necessities of life, and the moral poverty of those who are crushed under the weight of their own self-love. (POPE PAUL VI, 1967, p. 21).

\section{And identifies}

[...] oppressive political structures resulting from the abuse of ownership or the improper exercise of power, from the exploitation of the worker or unjust transactions' as factors causing this. He argues that Christian scripture $[\ldots]$ teaches us that $[\ldots]$ the earth truly was created to provide man with the necessities of life and the tools for his own progress, it follows that every man has the right to glean what he needs from the earth (and therefore) created goods should flow fairly to all. (POPE PAUL VI, 1967, p. 22).

$\mathrm{He}$ then proceeds to condemn the contemporary state of global capitalist system in no uncertain terms:

However, certain concepts

[...] present profit as the chief spur to economic progress, free competition as the guiding norm of economics, and private ownership of the means of production as an absolute right, having no limits nor concomitant social obligations. This unbridled 
liberalism paves the way for a particular type of tyranny, [...] for it results in the "international imperialism of money."(26) [...] [This] type of capitalism, as it is commonly called, has given rise to hardships, unjust practices, and fratricidal conflicts that persist to this day. (POPE PAUL VI, 1967 , p. 2-27).

This was the first time in history that the Vatican had taken such a clear political position against capitalism, and this had to have a strong and far reaching impact on the social and political consciousness of an overwhelmingly Catholic continent as Latin America.

Shortly after this historical event, the Second Conference of Latin American Bishops (SCGEL) was held in Medellín, Colombia, from 11 to 18 August 1968 (its final document was issued on 6 September 1968), in which the assembled bishops of the continent took a stance which was even more radical than that of the Populorum Progressio. It attacks the very essence of neoliberal capitalism, i.e. the right of private ownership of the means of production by the business enterprises.

The system of Latin American business enterprises, and through it the current economy, responds to an erroneous conception concerning the right of ownership of the means of production and the very goals of the economy. A business, in an authentically human economy, does not identify itself with the owners of capital, because it is fundamentally a community of persons and a unit of work, which is in need of capital to produce goods. A person or group of persons cannot be the properties of an individual, of a society, or of the state. (SECOND CONFERENCE OF LATIN AMERICAN BISHOPS, 1968, p. 10).

It upholds the rights of peasants and workers to organise in unions and secure social, economic and political rights:

[...] the peasants' and workers' unions, to which the workers have a right, should acquire sufficient strength and power. [...] They ought to exercise their right of being represented, also, on the social, economic, and political levels, where decisions are made which touch upon the common good (SECOND CONFERENCE OF LATIN AMERICAN BISHOPS, 1968, p. 11).

It talks about the need for Latin America "'[...] liberating itself from the neo-colonialism to which it is bound' through the solidarity and struggles of its people." (SECOND CONFERENCE OF LATIN AMERICAN BISHOPS, 1968, p. 13) and about the existence of internal colonialism within the countries of the continent, which it characterises as:

Extreme inequality among social classes: especially, though not exclusively, in those countries which are characterized by a marked bi-classism, where a few have much (culture, wealth, power, prestige) while the majority has very little. (SECOND CONFERENCE OF LATIN AMERICAN BISHOPS, 1968, p. 13).

And further elaborates it in the following way:

Without excluding the eventuality of wilful oppression, these forms manifest themselves most frequently in a lamentable insensitivity of the privileged sectors to the misery of the marginalised sectors. [...] these groups [...] (often) characterize as subversive activities that attempt to change the social system which favours the permanence of their privileges. [...] some members of the dominant sectors occasionally resort to the use of force to repress drastically any attempt at opposition. It is easy for them to find apparent ideological justifications (anti-communism) or practical ones (keeping "order") to give their action an honest appearance. (SECOND CONFERENCE OF LATIN AMERICAN BISHOPS, 1968, p. 3).

This position of the Catholic Church in Latin America were soon tested by the baptism of fire when military dictatorships and the US supported right-wing regimes in various Latin American countries began resorted to cruel repression to crush all forms of organised resistance by the poor and the marginalised. The liberation theology that emerged in Latin America did indeed frequently invoke these two documents for the doctrinal legitimacy of its pro-poor activities, but its real legitimacy in the eyes of the masses stemmed from its active and fearless support in the organisation of prosecution of resistance to the repressive actions of these regimes.

Liberation theology arose out of a growing unease that the Catholic clergy in Latin America felt with the shocking poverty and social inequality they saw all around them and the person who provided the main body of theory and intellectual power to it was Gustavo Gutiérrez, a Peruvian theologian and linguist. This is how he described the source of his inspiration: "Real Christian love is founded on commitment to a more just society and action to bring it about." (GUTIÉRREZ, 1971, p. 278). He further says that the

[...] challenge in a continent like Latin America does not come primarily from the man who does not believe, but from the man who is not a man, who is not 
recognized as such by the existing social order: he is in the ranks of the poor, the exploited; he is the man, who scarcely knows that he is a man. (GUTIÉRREZ, 1974, p. 69).

He unequivocally attributes all the ills of the continent to capitalism which is "[...] only system that really exists in Latin America, save Cuba." (GUTIÉRREZ, 1983, p. 113). In his book Teología de la Liberación he says that reforms that leave capitalism in place without seeking a radical transformation of its socioeconomic structure will achieve nothing, that development strategies being pursued in Latin America are not viable because they are all embedded in the existing system of international capitalism, that a truly liberating society cannot be reached by capitalist means. In The Power of the Poor in History he reiterates this position definitively and more bluntly: "Capitalist development is of its very nature detrimental to the masses." (GUTIÉRREZ, 1983, p. 85).

In the large corpus of his writings, he makes no effort to conceal the fact that, apart from Christian theology, the other main sources of his inspiration are Marx, Che Guevara and the Peruvian Marxist José Carlos Mariátegui. In his search for new insights in history, he advocates:

[...] the change from the capitalist mode of production to the socialistic mode; that is to say, to one oriented towards a society in which persons can begin to live freely and humanly. They will have controlled nature, created the conditions for a socialized production of wealth, done away with the private acquisition of excessive wealth, and established socialism. (GUTIÉRREZ, 1971, p. 20).

He argues that a necessary precondition for the achievement of such values as equality, solidarity and participation is a transition from private to social ownership to the means of production (GUTIÉRREZ, 1971), he admires Mariátegui as an outstanding scholar in the pursuit of the search for a creative and indigenous socialism and because he remains true to "[...] the central institutions of Marx [...]" as well as to "[...] a unique historical reality [...]" (GUTIÉRREZ, 1971, p. 56). He approvingly refers to Che Guevara to show that utopian thinking can be a guide to praxis and that socialism has to involve not just a new economic structure and a new kind of social consciousness (GUTIÉRREZ, 1971). He advocates the elimination of the private ownership of the means of production because that is the basis of an exploitative and classdivided society and because by appropriating the means of production "[...] the masses appropriate their own political management [...]" and "[...] their definitive freedom [...]", and this leads to a new social consciousness (GUTIÉRREZ, 1983, p. 37-38).
One of the iconic figures among the liberation theologians and activists in Brazil was Dom Pedro Casaldáliga, who became widely known as the red bishop (BRANFORD; GLOCK, 1985, p. 140). I dwell here on his life and work in a little more detail than on others of this school because I believe that he provides a basis for the writers of the left to liberation theology a little more seriously than has been the case so far.

He was ordained the bishop of the interior Amazônian diocese of São Félix do Araguaia on the $23^{\text {rd }}$ of October of 1971 . This diocese was twice the size of Portugal, where nearly all the land was organised in huge estates owned by extremely rich landowners and where rural landless workers were made to work on these estates under various forms of coercion and where indigenous communities lived under constant threat of invasion by land speculators (grileiros), loggers (madeireiros) and big estate owners (latifundiários). There he dedicated his life in supporting the struggles of these marginalised people against the violent oppression they faced. He sought to concientise these people and spread his message of hope amongst them by a copious output of pamphlets and poems, in which he freely mixed Christian imageries with what many regarded as revolutionary, subversive and even Marxist ideas. Here is an extract from one of his pamphlets:

Our Church is against the latifúndio and against slavery and for this reason it is persecuted by the Masters of Money, Land and Politics. Neither sharks (landowners) nor exploiters, nor traitors to the people have a place in our church. For no one belongs to the People of God if he crushes the Sons of God. (BRANFORD; GLOCK, 1985, p. 141).

Here is one of his poems written in 1972 taken from a collection of poems published under the title of Me Llamarán Subversivo (They Call Me Subversive):

Me llamarán subversivo, y yo les diré; lo soy Por mi pueblo em lucha, vivo; con mi pueblo en marcha, voy.

Tengo fe de guerilloro y amor de revolucíon $\mathrm{Y}$ entre Evangelico y cancíon, sufro y digo lo que quiero

Si escandalizo, primero, quemé el propio corazón al fuego de esta Pasión, cruz de su mismo Madero.

Inicito subversión contra el Poder y el Dinero.

Quiero subvertir la Ley que pervierte al Pueblo en grey $\mathrm{Y}$ el gobierno en carnicero.

(Mi Pastor se hizo Cordero, Servidor se hizo mi Rey.

They will call me subversive, and I'll tell you; who I am By my people in struggle, I live; with my people, I will. 
I have faith of the guerrilla, and love of the revolution And between the Evangelical and the song, I suffer and I say what I want.

If I scandalise, first I burn my own heart In this fire of passion of his Cross of the same wood.

I encourage subversion against Power and Money.

I want to subvert the Law that turns the people into a flock of sheep And the government into a slaughterer.

(My Shepherd became a Lamb, my King became a servant. (CASALDÁLIGA, 1972).

Predictably big landowners had mounted a campaign to have Dom Pedro expelled from the country and this was vigorously taken up by most of the media. In 1977 Edgardo Erichsen, the director of the powerful Globo TV and radio network, at that time closely allied with the military dictatorship, had launched this virulent attack against the bishop:

It seems that the bishop has exchanged his crucifix and rosary for the hammer and sickle, his prayer book for the thoughts of Mao Tse-tung, his priestly piety for violence and that he is only waiting for the right moment to exchange his cassock for a guerrilla's uniform. Of some left-wing priests it can be said that they light one candle to God and the other to the devil. But for Bishop Dom Perdro Maria Casaldáliga, the least that can be maintained is that he lights both candles to the devil. (BRANFORD, 2013).

In 1985 he travelled to Nicaragua to express solidarity with the Sandinista government and with the priests who were increasingly becoming targets of assassination by the US-supported contra guerrillas. The visit had invited a swift rebuke from the Vatican. In 2003 he resigned from his post of bishop but decided to stay on in São Félix do Araguaia, ignoring the Vatican's advice to leave the area. In January 2013 he was reported to be in hiding because of death threats from the local landowners (BRANFORD, 2013; DIARIO ..., 2004; ESCRIBANO, 2002; VIDAL, 2006).

One of Dom Casaldáliga's associates and fellow priests murdered by the police on 11 October 1976 was João Bosco Penido Burnier at Ribeirão Cascalheira in the State of Mato Grosso. He, along with Dom Casaldáliga, was interceding with three policemen who were beating up two peasant women, when one of the policemen delivered a blow to his face and then shot him dead (MAIA, 1981). It was the period of the dictatorship of Ernesto Geisel, probably the cruelest period of the repression of the rural workers and landless peasants in modern Brazilian history, when the police and military personnel enjoyed a general sense of immunity for their acts, including killings. The killer of João Penido was never prosecuted.

Another key proponent of liberation theology is Hélder Câmara. He was born in Fortaleza, Brazil and served as the Archbishop of Olinda and Recife from 1964 to 1985 , which was the period of military rule in that country. Responding to the Brazilian right's constant refrain that those demanding social justice and raising issues of poverty and inequality are just Marxist agitators, Câmara had responded with these unforgettable words:

Quando dou comida aos pobres chamam-me de santo. Quando pergunto por que eles são pobres chamam-me de comunista (When I give food to the poor, they call me a saint. When I ask why the poor have no food, they call me communist). (ROCHA, 2000, p. 53).

His philosophy and doctrine is outlined in his famous book Spiral of Violence (CÂMARA, 1971). In this book he argues that injustice in all its forms is the central issue of humanity in the contemporary world, it is the basic violence, Violence No. 1. This attracts Violence No. 2, e.g. violent struggles of the oppressed for a more just world, which in turn attracts Violence No. 3, the State's violent repression of these struggles, often in the name of anti-communism. In this context he points out "[...] monolithic and obsessional anti-communism is responsible for many absurdities." (CÂMARA, 1971, p. 34). Justice is also essential for maintaining peace because

[...] a peace based on injustice - the peace of a swamp with rotten matter fermenting in its depths - we may be sure that that peace is false. (CÂMARA, 1971, p. 32-33).

He acknowledges Gandhi as a prophet and argues that a true response to all three different kinds of violence is "[...] the violence of the peaceful: liberating moral pressure." (CÂMARA,1971, p. 55). This will be achieved by building a worldwide movement called Action for Justice, which must include not only Catholics, but people of all religions.

The time has come when each religion must rediscover, in its sacred texts, the truths capable of encouraging the human development of the outcasts of the modern world and of arousing the consciences of the rich. (CÂMARA, 1971, p. 71).

\section{It must also reach out to atheists because}

[...] when you meet people for whom the love of God involves human love, your atheism will give way to respect (and) to sympathy. (CÂMARA, 1971, p. 80). 
Populorum Progressio and the ideas of Latin America's Liberation Theology, which to a degree was inspired by it, had found very little acknowledgement, much less acceptance, in Catholic church hierarchies in North America and Europe, a fact not entirely lost on the Latin American thinkers, when the US bishops issued their Pastoral Letter on economic issues entitled Economic Justice for All in 1986, generally talking about poverty and injustice, without identifying those structures of the economy which gave rise to them, it came in for fierce and blunt criticism from the Latin American clergy:

Capitalism can be more or less immoral; it can never be more or less moral. You do not eliminate the ferocity of the wolf by filing down its teeth ... It is just as impossible to create a moral market system as it is to build a Christian brothel. (BOFF; BOFF apud MCGOVERN, 1989, p. 139).

Similarly Archbishop López Trujillo (apud MCGOVERN, 1989, p. 19) of Colombia had also said: "We are convinced that capitalism is a human failure."

McGovern clearly identifies the reason why liberation theology must always be the cause of a fundamental schism between the Catholic Churches in Latin America and Western Europe/ North America:

One reason liberation theologians opt for socialism stands out above all others: their abhorrence of the prevailing capitalist system. If, as many liberation theologians stress, capitalism cannot be reformed to meet the basic needs of the poor or to give them true participation in society, then socialism seems to be the only real option. (MCGOVERN, 1989, p. 139).

It was of course anathema to the North American and Western European wings of the Catholic Church hierarchy to countenance any criticism of the fundamentals of capitalism.

Cardinal Joseph Ratzinger (2004), a conservative German cleric who was elevated to the position of Pope in 2005, stated categorically that liberation theology

[...] constitutes a fundamental threat to the faith of the Church ... (while) At the same time it must be borne in mind that no error could persist unless it contained a grain of truth.

He laments that

[...] it affects (Christian) theology in its basic constitution [...] alters all forms of church life: the Church's constitution, liturgy, catechesis, moral options. (RATZINGER, 2004).
Furthermore, in his view, it pronounces Christian theology as

[...] not practical; i.e. not essentially political (therefore) idealistic and thus as lacking in reality, or else it is condemned as a vehicle for the oppressors' maintenance of power.

We shall only survive this crisis if we succeed in making the logic of faith visible in an equally compelling manner and in presenting it as a logic of reality[, he says].

In other words, he cautions Catholics not to allow this threat or this crisis to overwhelm them, and to remain steadfast in their faith in the Church's centuries' old conservative practices which never questioned injustice and inequality (RATZINGER, 2004).

A more balanced appreciation of, and a degree of support to, liberation theology has come from some Catholic clerics from the North, among who are Peter Burns of Scotland and Arthur McGovern of the United States. Burns (1992) agrees that liberation theory has generally taken a left-wing, but not a purely Marxist, political posture, and argues that, given the specific historical situation of Latin America, that stance was quite justified. Both capitalism and tercerismo (Third Way) had become thoroughly discredited in that continent and socialism therefore was a logical choice. He points out that Gutiérrez had specifically rejected the Stalinist kind of socialism way back in 1971 (BURNS, 1992). He leaves no one in any doubt about his position of strong support with regard to the liberation theology:

My fear is that liberation theology will be coopted (seduced?) by the theological establishment, and have all its potential for threatening the existing order of things tamed or drained out of it in consequence. This fear will be realized much more swiftly if liberation theology ever capitulates to the current ideological hegemony of capitalism, and forsakes the search for an authentic, well-defined and feasible alternative. [...] At this crucial turning point in ideological history, to leave the povertystricken masses of the Latin continent to the not so tender mercies of a resurgent, triumphalistic global capitalism, and to bow before the idol of free-market economics, would be a tragic act of betrayal. (BURNS, 1992, p. 515).

McGovern's support is a lot more qualified. His core argument is that liberation theology is not all that threatening to the capitalist system and therefore need not cause much alarm. After all what its proponents favour is only "[...] a system that truly represents the vast majority of the people [...]"; "[...] a socialism without the deficiencies of existing socialist countries 
[...]" (MCGOVERN, 1989, p. 124). Its programme is not likely to be any more radical land reform in favour of peasants, a mixed economy comprising state, collective and private enterprises, high priorities to food security, medical care and education, full political democracy, a free press and a freedom of religion. Such a programme should not worry anyone in the capitalist world (MCGOVERN, 1987).

Alistair Kee (1990), a Marxist theologian from Scotland, criticises liberation theology from an entirely different perspective. He says that:

Latin American theology of liberation is widely assumed to be too Marxist: in reality it is not Marxist enough. It is frequently criticized for its unquestioned acceptance of Marx: on a closer inspection there are crucial aspects of Marx's work which it simply ignores. (KEE, 1990, p. 9).

According to Kee (1990), liberation theology failed to pay enough attention to three core criticisms of religion by Marx that (i) it encourages adaptation to, and reconciliation with, unjust social systems; (ii) inverts ontology to justify and legitimise unjust social arrangements; and (iii) uses an ideology which is designed to promote societal false consciousness.

Kee argues that liberation theologians have failed to understand how the oppressors invert ontology for securing and justifying and their own status and making people believe that the suffering of the poor is predestined. This inversion is embedded in their failure to recognise that:

[...] [the] knowledge of God does not come through a religious sphere, through religious actions, intentions or attitudes. The radical nature of the divine transcendence is not that God exists in another ontological dimension inaccessible to human beings, but that God cannot be objectified, cannot be approached except through the quest of justice. (KEE, 1990, p. 205).

\subsection{India's subaltern and Dalit literatures and their relevance to Brazil and the wider world}

In the 1980s, a group of left-leaning Indian historians started writing the histories of a series of peasant uprisings across the country against the British colonial rulers and their Indian collaborators which had taken place in regular frequencies from the 1730 s onwards. What they were seeking to do was to produce an alternative historiography of struggle and conflict which looked at each individual case not through the eyes of the dominant classes who controlled and managed the apparatus of repression but sought to capture the perspective of those who resisted them and rebelled against them. They were aware that the primary source documents of history are always written and handed down to posterity by the dominant classes. They understood that an alternative historiography in which the masses and not the elite are the drivers of the narrative could only be written by re-reading and re-interpreting the same documents in the light of a new hermeneutics and ontological repositioning of the writer. The principal authors of this school of writing were Ranajit Guha (1982; 1983) and many others (CHATTERJEE, 1983; DASGUPTA, 1985; SARKAR, 1985; HARDIMAN, 1987). The core driving force of the subaltern theory is this:

[...] parallel to the domain of elite politics there existed throughout the colonial period another domain of Indian politics in which the principal actors were not the dominant groups of the indigenous society or the colonial authorities but the subaltern and intermediate strata in town and country - that is the people. (GUHA, 1982, p. 4).

This domain in India has also been very diverse; ethnically, occupationally, spatially and in terms of the multiplicity of castes. Despite this, it has always acquired a consciousness of togetherness, of sharing a common interest, of class, through a

[...] notion of resistance to elite domination ... (which) followed from the subalternity common to all the social constituents of this domain. (GUHA, 1982, p. 5).

It has always derived its strength and fighting spirit "[...] from the condition of exploitation." (GUHA, 1982 , p. 5) its diverse subaltern classes had been subjected to in various ways.

Gramsci (1971) was an important source of inspiration for the subaltern writers, particularly his use of the concept of negation in the rise of class consciousness among the subordinate classes. He writes:

The lower classes, historically on the defensive ... can only achieve selfawareness via a series of negations, via their consciousness of the identity and class limits of their enemy. (GRAMSCI, 1971, p. 273).

Therefore, when they close ranks and unite in solidarity to rise in revolt against the authority of the dominant classes, that is the moment when they take the first step towards class consciousness,

[...] merely as the first glimmer of such consciousness, in other words, merely as the basic negative, polemical attitude. (GRAMSCI, 1971, p. 273). 
This is the lesson that the subaltern writers were seeking to draw when they were focusing so such meticulous attention on the details of so many uprisings and insurgencies of the peasants and aboriginal communities against the British rulers and their domestic collaborators in colonial India.

But as Guha (1983) has clearly shown, the insight gained through these studies need not only be used to illuminate the events of the past, but also to shed light on the pathways to the future. Because,

[...] if the task of historiography is to interpret the past in order to help in changing the world [...] (then) such a change involves a radical transformation of consciousness. (GUHA, 1983, p. 336).

This insight does not need to be limited to India. It may have lessons for all the peoples across the world who are struggling against the elitedominated system which can only guarantee to the $99 \%$ increasingly greater inequality, greater injustice, worsening poverty and hopelessness.

The problem of theorising the emergence of class consciousness in this way is that the product essentially becomes localised and spatially fragmented and therefore it becomes extremely difficult to transform it into an overarching national consciousness. The basic framework for achieving this task is however available in India's own ancient history. The Vishnu Purana (Book 2, Chapter 1, verses 31 and 32), a Hindu religious text which is variously dated between the years 275 to 400 of the Christian calendar, defines the territorial extent of India and its national identity thus:

Therefore, $\mathrm{O}$ thou of Puru's race, cherish thy exalted son born of Queen Sakuntala and because this child is to be cherished by thee even at our word, therefore shall this thy son be known by the name of Bharata (the cherished). The country that lies north of the ocean and south of the snowy mountains is called Bhāratam; there dwell the descendants of Bharata (WILSON, 1840).

Most foreign scholars living outside India may not know this, but India is a name given to it by the British. Indians still refer to their country as Bhārat and not India, as the Germans refer to theirs as Deutschland and not Germany.

Ancient sages who wrote Vishnu Purana imagine here a national identity which transcends the subcontinent's myriad pluralities and fragmented local identities. This they did by means of a creative mixture of mythology and territoriality. This imagination has stuck firmly over centuries in the collective memory of the Indians in the shape of this powerful visualisation of Mother India as a concrete reality. The imagery was vividly used by Bankim Chandra Chatterjee in his epic work of fiction, Anand Math, written in 1822 and by Rabindra Nath Tagore in his poem Bharata Teertha written in 1910 to inspire the Indians during their long-drawn struggle for independence.

There is some evidence that India's subaltern theory has had an impact, albeit very limited, on the Brazilian thinking regarding identity. But this impact has found its expression in a very curious way. Gazi Islam, based at the Instituto de Ensino e Pesquisas, São Paulo, finds a common ground between subaltern theory and anthropophagy. He believes that anthropophagy is "[...] the most potent and durable metaphor in modern Brazilian Culture." and suggests that "[...] [it] can complement subaltern and orientalist perspectives.", pointing out, at the same time, that across the world, it has had "[...] a rich history mediating relations between the civililized core and the barbarous peripheries." and that

[...] alleging cannibalism was a form of 'othering', framing an exotic society in barbarous terms to establish self-other boundaries. (ISLAM, 2011, p.1).

The Brazilian anthropologist Maria Almeida Candida Ferreira (2002a; 2002b) argues that anthropophagy is an affirmative rather than a defensive metaphor because it ídevouring European culture. In a similar vein, the American anthropologist Shirley Lindenbaum claims that:

Adopting a cannibal identity transformed a taboo into a totem and redefined anthropophagic primitivism as a positive value - witty and self-reflective critique of colonialism. (LINDENBAUM, 2004, p. 493).

Whichever way one looks at anthropophagy as a metaphor for a hybrid culture and ethnicity, and whatever positive construction one seeks to confer on it, it would seem that in every case of contact between the Europeans and the indigenous nonEuropean peoples, it puts the former in a civilising role and the latter as peoples without histories needing to be civilised. This is not the message which either the Subaltern Literature of South Asia or the Orientalist construction of history by Edward Said seeks to convey.

I am not sure if the anthropophagy is a helpful metaphor for approaching the issue of identity in Brazil or even useful as a medium of progressive hermeneutics anywhere. It may be the case that Gilberto Freyre's (1933) highly sexualised account of social contacts between Brazil's various racial identities and Darcy Ribeiro's (1995) concept of cunhadismo will provide more progressive, more humanising, and therefore, better intellectual frameworks for defining the narrative of Brazil's social formation and its composite identity than the metaphor of anthropophagy (FREYRE, 1933; RIBEIRO, 1995). 
India's Subaltern Literature no doubt makes a valuable contribution to the development of an alternative non-elitist post-colonial theory. We need to recognise, however, that there also exists a parallel strand of 'subaltern' literature which has had a much greater impact on the political mobilisation of the underprivileged classes in India. This strand is known as the Dalit literature and has been inspired by the political activism of iconic revolutionary figures like Jyotirao Phule (1827-1890), Bhimrao Ramji Ambedkar (1891-1956), Periyar E.V.Ramasamy (1879-1973) and Kanshi Ram (1934-2006). Unlike the authors of the subaltern literature, nearly all of whom are Bengali speaking Brahmins and Kayasthas, belonging to the upper echelons of the Hindu caste hierarchy, the Dalit writers are all from the lowest fringes of Hindu society, mainly from Maharashtra, Tamil Nadu and Uttar Pradesh, but more recently, from other parts of India as well. Bengalis are conspicuously absent from this school of authors. The word Dalit in all Indian languages means the oppressed and the main focus of the Dalit literature is the historicity of struggle of the oppressed castes within the Hindu society against a governing structure monopolised by the people belonging to the Hindu upper castes. The essence of the Dalit project is to redefine Indian history from the perspective of all of India's oppressed people, where the main oppressors are not only the colonialists but India's own caste hierarchy.

\subsection{Gilberto Freyre, Darcy Ribeiro and Celso}

Furtado: what do they have in common with India's subaltern and Dalit theories

Freyre acknowledges the mixed-race origins of the Brazilian identity but romanticises it as a harmoniously evolving process.

The majority of our countrymen are the near descendents either of masters or of slaves, and many of them have sprung from the union of slave-owners with slave women. (FREYRE, 1933, p. 1214).

This process of the fusion of races and union of cultures in Brazil is said to have evolved without race hatred, unlike the United States, because it "[...] had been softened by the hot climate and by the effects of a miscegenation that tended to dissolve such prejudices." (FREYRE, 1933, p. 12-14). Interpreting the Brazilian society of the 1930s and 1940 s in the light of this synthetic principle he judges that it has been moving in the direction of a broad democratization tending "[...] to mollify the interclass and interracial antagonisms." (FREYRE, 1933, p. 1214). His characterisation of the relationship between the whites and the blacks in Brazil during the period of slavery as one of the most harmonious unions of culture with nature, seems to be a grotesque historical amnesia.

Ribeiro's (1996) conceptualisation of Brazil's composite national identity definitely marks an advance on that of Freire. He looks at the process straight in the face:

We have arisen out of a confluence, a collision, and a melting pot of the Portuguese invader with plains- and forest-dwelling índios (aboriginals) and with African blacks, both groups coerced into slavery. (RIBEIRO, 1996, p. 19).

Sometimes, what he says seems to be too good to be a true, simply a projection of his wishful aspiration:

More than a simple ethnicity, however, Brazil is a national ethnicity. [...] Brazilians are integrated into a single national ethnicity, constituting in that way a single people incorporated into a unified nation, in a uni-ethnic state. (RIBEIRO, 1996, p. 22).

óThis has come about

[...] through processes so repressive and violent in governance that they constituted a continuous genocide and an implacable ethnocide. (RIBEIRO, 1996, p. 23).

He presents a vivid picture of the objectification and sexual brutalisation of the aboriginal women by the early Portuguese settlers.

Their obsessive desire was to multiply themselves in the wombs of the aboriginal women and to put the women's arms and legs in their service to plant and harvest their crops and to hunt and fish for what they ate. [...] These captive aborigines [...] were also the providers of their joys, especially the women, with good sex organs to fornicate, good arms for work, and fertile wombs to impregnate. (RIBEIRO, 1996, p. 48).

Some of these early contacts with the aborigines were more consensual and less brutal. This took place through a process which Ribeiro called cunhadismo, This involved the early settler setting up stable conjugal relationships with several aborigine girls with the consent of the tribe, and establishing a wide network of affinity kinships, temericós, through the relatives of these girls. Through this process many early settlers sired countless numbers of mixed-race children, grandchildren and grand-grand-children: "Without this 
practice of cunhadismo, the creation of Brazil would have been impractical." (RIBEIRO, 1996, p. 81-86).

The incorporation of enslaved Africans into Brazil's national ethnicity was also no less brutal. Ribeiro fully recognises the national shame which had given rise to its composite national identity and emphasises the need for keeping that fixed in the nation's collective memory as a kind of cleansing therapy.

All of us Brazilians are the flesh of this flesh of those tortured blaks and aborigines. All of us Brazilians are, likewise, the mad hand that tortured them. The tenderest softness and the most atrocious cruelty come together here to make us the sensitive and longsuffering people that we are and the insensitive and brutal people that we also are. Descendants of slaves and slave owners, we will always be slaves to the distilled malignancy installed in us because of the feeling of the pain intentionally produced in order to give more pain and because of the exercise of brutality over men, women, and children that has been the nourishment of our fury. [...] The most terrible aspect of our heritages is that we will always carry with us the mark of the torturer impressed on our soul [...] By provoking growing indignation, however, it will give us the strength tomorrow to rein in the madmen and create a society of solidarity here. (RIBEIRO, 1996, p. 120)' 1 .

He strongly criticises Freire's racial democracy thesis. He points out that despite the fact that the Brazilian society is a product of widespread miscegenation,

[...] that situation did not go on to shape a racial democracy, as Gilberto Freyre and many others would like to believe, because of the heavy weight of anti-black oppression, prejudice, and discrimination present.

[...] because the very expectation that the black would disappear through miscegenation is a form of racism. (RIBEIRO, 1996).

This may not create a purely racial form of prejudice that leads to apartheid, but it gives rise to a situation in which:

[...] blackness is diluted on a broad scale of gradations, which breaks solidarity and reduces combativeness by insinuating the idea that the social order is a natural order, even a sacred one. The most perverse aspect of assimilationist racism is that it gives itself an image of greater sociability, when in fact it disarms the black in his fight against against poverty that has been imposed on him and conceals the conditions of terrible violence to which he has been submitted.

[...] se dilui a negritude numa vasta escala de gradações, que quebra a solidariedade, reduz a combatividade, insinuando a idéia de que a ordem social é uma ordem natural, senão sagrada. $\mathrm{O}$ aspeto mais perverso do racismo assmilionista é que ele dá de si uma imagem de maior sociabilidade, quando, de fato, desarma o negro para lutar contra a pobreza que lhe é imposta, e dissimula as condições terrível violência a que é submetido. (RIBEIRO, 1996, p. 226).

After all this is said and done, Ribeiro (1996) still builds an identity for Brazil after the image of the Roman soldier encamped on the Iberian peninsula. To him

[...] the ideal conditions for ethnic transfiguration were attained through forced de-indigenisation of the aborigines and de-Africanisation of the blacks. (RIBEIRO, 1996, p. 452).

But the need for the de-Europeanization of the Portuguese nucleus in terms of the point of reference of a new national identity, is not even mentioned. The Brazilians must maintain their Romanness (romanidade) and Latinness (latinidade). This is an identity of "[...] a new Romanness, a late but better Romanness, because it has been washed in aborigine and black blood." (RIBEIRO, 1996, p. 453). It is on the basis of this identity that Brazil must chart its destiny which is "[...] to join with all Latin Americans in our common opposition to the same antagonist, which is Anglo-Saxon America." (RIBEIRO, 1996, p. 452-454). It is the dream of "[...] a New Rome - a latter-day, tropical Rome." (RIBEIRO, 1996, 452454). Will the blacks and the pardos feel valued in this new Rome?

I have always felt, and said so (SAHA, 2012), ever since I came in contact with Brazil in 1989, and during my numerous visits to, and extended stays in the country since then, that there are three fundamental constitutive strands to its identity - its indigenous roots and those of its European and African settlers, the former arriving here in freedom, the latter, in slavery. It cannot therefore make any ontological sense to approach the identity issue in Brazil without fully reflecting these three strands of historical realities and life experiences of its peoples, and the inextricable hybridism, fusion and synthesis they have produced over five centuries of coexistence. If Brazil is really open to the future, and if it is

[...] to flourish as a new civilization, of mixed blood [...] better for incorporating 
within itself more humanities; and more generous for being open to all races and all cultures. (SAHA, 2012, p. 455).

As Ribeiro believes, it needs to begin by valuing all the strands of its social fabric in equal measure.

In a speech given at a national seminar in Belo Horizonte on the $23^{\text {rd }}$ of April, 1984, Celso Furtado, the celebrated Brazilian economist and philosopher, also emphasised the issues of identity and culture, particularly in the context of determining the priorities of development, and posed the provocative question who are we, a question that, he believed, a nation must address in its moments of crisis. "A reflection on our identity will necessarily be the starting point of the reconstruction process that lies before us [...]" and also "[...] any discussion about development options for Brazil should be based on a study of Brazilian culture." (FURTADO, 1984 , p. 44-45). In any country the questions of identity and culture are inextricably rooted in its history, which is why, he relates his seven theses on Brazilian culture to the defining moments of its history. "Brazilian culture is one of the many fruits of a mutation process that took the form of an overflow of European culture since the beginning of the XVI century" (FURTADO, 1984, p.).

In Brazil's case the source of this overflow was Portugal. Therefore:

During the three centuries of colonial era, Brazil experienced the development of a culture that, while being Portuguese in spirit and style, at the same time included not only local motives but also the values of subjugated cultures. (FURTADO, 1984, p.).

"While Aborigines and Africans were isolated from their respective cultural roots and deprived from historical memory" (FURTADO, 1984, p.), they still made significant contributions in the enrichment of this composite culture. The synthesis represented in the Brazilian Baroque symbolised a glorious efflorescence of this fusion of cultures, "[...] the expression of a society as a whole (whose) message was received by masters as well as by slaves". (FURTADO, 1984, p. 47).

After the onset of the Industrial Revolution in Europe around the 1870s, however, the courses of historical development in Europe and Brazil diverged.

Dependent modernization in Brazil made the end of its Baroque synthesis lead to Bovarism instead of leading to new creative cultural processes - as was the case in Europe, where medievalism gave way to humanism. [...] Nobody can fail to see that our belated industrialization followed an imitative pattern that went to reinforce the already deeply rooted tendencies of our society towards elitism and social oppression [...] The accumulation process was put to the service of unbridled modernization in the life styles of middle and upper income strata, leaving the satisfaction of needs of the masses in absolute oblivion. (FURTADO, 1984, p. 48).

This was the mistaken role, the Bovarian role, that the elite started playing in colonial Brazil, and the elite and the middle class are still playing in contemporary Brazil. But he reminds the middle class that it can play a more progressive role in the building of Brazil if it were to choose to do so:

The middle class constitutes a privileged locus of cultural creation and moves between dependent modernization and the search of an identity that can only be found in popular roots. The concentration of income is nothing but the other face of dependent modernization. Hence a new cultural synthesis that reflects the creative power of the people requires a deepening of the democratic process and the reduction of social differences. (FURTADO, 1984, p. 49).

If Brazil is to rediscover its identity founded in its popular root, and if its middle class is to play the progressive role that Furtado thinks it can, it has to begin to value and respect its African and indigenous roots at least as much as it values its European one. What the Indian poet Rabindranath Tagore had said to the Indian elite in 1910 in a poem called Opomanito (Humilhado) now holds good for Brazil too:

O my ill-fated country, those you have given only humiliation

Time has come for you to share that humiliation with them

Those you have even denied the right to be human

Those who have always lived near you, But you always pushed them away with hatred and contempt Time has come for you to share that humiliation with them. (TAGORE, 1910b, p. 509)2.

6 CONCLUSION: the $99 \%$ can build a different future if they learn to act politically

The first step to act politically is to understand that the process that creates limitless wealth for some also creates worsening poverty and terrible misery for many and to cleanse the minds the many of the illusions of false hopes that one day, they too will share in that wealth and that lifestyle that the rich and the super-rich currently enjoy.

The stories of rags-to-riches which the media and the higher education system, currently under 
the ever-tightening grip of the richer classes, so assiduously spread and a few scholarships to higher education that these classes offer to the poorer students while at the same time blocking in a calculated way access to the millions of other poorer students to the same opportunity, are all parts of this carefully orchestrated campaign of sustaining this illusion in the minds of the $99 \%$. Also parts of this campaign are the charities like Oxfam, ActionAid, Save the Children, Christian Aid, those maintained by the Catholic Churches across the world and the various foundations which the richer classes patronise and support. The television pictures of people from these organisations feeding the malnourished children, providing health care, creating safe drinking water facilities and doing many other good things into beamed into the houses of millions of people every day, including the wretched shacks of those living in slums, shantytowns and favelas help to perpetuate the image of capitalism as a benevolent system, while taking away the focus of attention from the fact that that precisely is the system which keeps a million times more number of children in malnourishment, denies them and their parents the healthcare they need and should expect to have in any civilised system and brings those favelas and shantytowns into existence in the first place.

Another lie that needs to be debunked is that the rich in every society are the wealth creators and employment generators and therefore attacking them in any way or putting limits on how much money they can make for themselves and how little they can pay who work for them, will be hurting the whole society. What the people need to be helped to understand is that all socially productive work is socially collaborative work and how much of the joint output of that collaborative work capitalists take as profits, finance providers as interests, the state as taxes and the workers of various categories as wages at various levels will depend on the value systems of the society prevailing at the time (what differentials are acceptable and judged as fair) and the rules of the game that the state has put in place to govern this. If the richer classes exercise a disproportionate influence in the state's policy making, regulatory and management functions, as is the case in most capitalist democracies across the world to various degrees, the rules of the game will always disproportionately benefit those richer people. Even Stiglitz agrees that most of the rich in the United States made their money not out of hard work and enterprise but out of the rent incomes of speculation and by exploiting privileged opportunities the state created for them.

The rich are so rich because the society and the state make it possible for them to take a disproportionately high share of the joint output of socially collaborative work, i.e. output jointly produced by capitalists, providers of finance and workers produced together. The poor are so poor because they are allowed to take home a disproportionately low share out of that jointly produced output. As long as the rules of the game remains like this, and the society continues to find this acceptable, the rich will continue to become richer and the poor will continue to be pushed into ever deepening states of poverty and deprivation, no matter how hard they work and how efficiently the system functions.

The third lie that needs to be debunked is that the quality of life of the poor can be made better without hurting the interests of the rich, i.e. without changing the rules of the game or the prevailing value systems of societies. We need to understand that it is impossible for the poorer $80 \%$ of the Brazilians or Indians to enjoy a quality of life that their own richest $10 \%$ of the compatriots are currently enjoying, never mind those being enjoyed by the richest $10 \%$ of the Europeans and North Americans without a total collapse of the planet earths ecological system or without a total exhaustion of its renewable and non-renewable natural resources. Such talk is only a part of this relentless campaign of sustaining the illusion in the minds of the poorer people that, if they worked hard enough, their children will one day enjoy the same quality of lifestyle that their bosses are enjoying today. The question therefore comes down to this: how much disparity in the quality of life between the richest and the poorest does the society find acceptable.

We must not forget that the Brazilian society in the $18^{\text {th }}$ and the $19^{\text {th }}$ centuries found the horrors of slavery acceptable. Gilberto Freyre, writing in the 1930s, was describing these absolute horrors without showing the slightest bit of revulsion and distaste, even judging them as part of an overall social dispensation which was in the main fair. The British society in the times of Charles Dickens found it quite acceptable that a hungry child could be sentenced to death for the crime of stealing a loaf of bread. The Indian policy makers and its intellectual classes today and find it quite acceptable that $48 \%$ of its children continue to remain in a state of malnutrition after 68 years of independence while they make rules pronouncing that anyone earning more than US 0.42 cents a day in the rural areas and 53 cents a day in urban areas are not poor and therefore not eligible to the meagre benefits that the state is supposed to make available to the poor.

During the ten years of PT government since 2003, Brazil has no doubt made significant advances in poverty alleviation and reducing inequalities. Even now, however, the level of inequality here is among the highest in the world. The minimum salary in Brazil since the beginning of 2013 is 678 reais or 288 US dollars per month or just over 22 reais/9 US dollars per day. At that level of income life will be very basic indeed in today's Brazil. It will be precarious if the head of the family has to support non-working dependents, as will be the case in most 
families. According to the sample survey figures just published by Brazil's National Statistics Office, in 2011 , the heads of $27 \%$ of Brazilian households earned less than the minimum wage; $14.1 \%$ less than half the minimum wage. More than a quarter of Brazilians thus continue living in extreme levels of poverty even after 12 years of PT government: of which, more than $14 \%$ in desperate (INSTITUTO BRASILEIRO DE GEOGRAFIA E ESTATÍSTICA, 2012, table 5.1).

The minimum wage in Brazil today is at an alltime high in real terms. Therefore, any suggestion that this may not be enough will certainly invite howls of indignant protest from the country's richer class. Brazil cannot afford it, they will say, like the US Congress says that that country cannot afford President Obama's healthcare plans for the poor; like David Cameron of Britain says that his country cannot afford its National Health Service (the universal free healthcare for all) and welfare payments to the poor at their present levels. But we need to ask the richer classes of these and other countries why can't they afford it?

Let's take the case of Brazil. In 2013, the country had 46 dollar billionaires, who's combined net worth was US\$ 189.3 billion. Where did this huge fortune come from? The richest of the 46 , Jorge Lemann made his money in beer, banking and retailing, 9 others including Joseph Safra made it in banking, six others, in media and television. In all the 46 cases, money was made by means of gaining preferential access to the country's natural, human and financial resources with the help of the state, paying low wages to the workers relative to the international rates, taking advantage of the protected domestic market during the period of the military government, lax labour laws and paying low taxes to the state because of an industrial policy which has always favoured businesses at the expense of labour. I have explained the process in greater detail in a keynote paper that I had presented at the ANPEC annual conference 16 years ago (SAHA, 1997). In other words, all of this wealth was extracted out of the Brazilian society and produced by the hard work and dedication of the Brazilian workers who had worked for the likes of Jorge Lemann, Josepf Safra, Antonio Moraes and 43 others. Looking at a broader scale, $43 \%$ of Brazil's GDP accrues to the richest $10 \%$ of its population; the highest proportion in the world. This bigger pot of wealth is also a product of the labour of the Brazilian workers, a disproportionately large share of which was taken by the bosses with the help of the state. If a fair share of this pot is allowed to be recycles to the benefit of all, through progressive taxes and a better division of the output between wages and profits, Brazil and all countries of the world can afford quality free universal health care for all and free access to education for all.
This will not happen until a reconfiguration of class alliances within societies bring about a reconfiguration of the nature of the state. The $99 \%$ after all is an euphemism, a figure of speech. Some intellectual effort needs to be invested in looking at the internal architecture of, let's say, the poorer $90 \%$. If we accept that the real division of society is between the top $10 \%$ and the bottom $20 \%$, then the political behaviour of the middle $70 \%$ will determine the nature of the state and its politics. It is unlikely that the top $9 \%$ below the top $1 \%$ will ever see a commonality of interests with bottom of $20 \%$. A major part of the bottom $20 \%$, without access to quality education, quality healthcare, adequate means of livelihood, would have been sinking into an ever deepening state of hopelessness and alienation; into a state of political inertness. A lot will depend on whether the rich are able to continue to sell to the broad middle-ground of $70 \%$ those brainnumbing rag-to-riches illusions, the fraud of the impossible dream of a credible chance of making to the top through hard work. Once these illusions are debunked, the $70 \%$ will rapidly see that they have nothing to gain by staying on the side of the top $10 \%$ and have everything by concentrating their efforts on creating a fairer and juster society and in that efforts, the bottom $20 \%$ will become their natural allies.

Once this reconfiguration of consciousness takes place, political parties which gain control of the state with the support of the top $10 \%$ and with the populist slogans addressed to the middle $70 \%$, will no longer be able to do so. Either these parties will disappear and new parties will emerge to promote the interests of the bottom 90, or the existing parties like Partido dos Trabalhadores in Brazil, the Peronistas in Argentina and similar other left-of-the centre parties across the world will be restructured from within under the pressure of this newly reconfigured electorate.

This can happen if intellectual efforts are invested to make this happen.

\section{BIBLIOGRAPHY}

ANDERSON, Benedict. Imagined Communities: reflections on the Origin and Spread of Nationalism. London: Verso, 1983.

BASTAGLI, Francesca; COADY, David; GUPTA, Sanjeev. Income Inequality and Fiscal Policy: IMF Staff Discussion Note. Washington, DC: International Monetary Fund., 2012.

BOURGUIGNON, François; MORRISSON, Christian. Inequality among World Citizens: 18201992. The American Economic Review, Pittsburgh, PA, v. 92, n. 4, p. 727-744, 2002. 
BRANFORD, Sue. (2013). The "Red Bishop" of the Amazon, London: Latin America Bureau. [S.I.:s. n.], 2013, Available in: :<http://lab.org.uk/the-red-bishopof-the-amazon>. Accessed on: 20 jul. 2013.

GLOCK, Oriel. The Last Frontier: Fighting Over Land in the Amazon, London: Zed Books, 1985.

BURNS, Peter. The Problem of Socialism in Liberation Theology. Theological Studies, Milwaukee, WI, v. 53, p. 493-516, 1992

CÂMARA, Hélder. Spiral of Violence. London: Sheed and Ward Ltd., 1971.

CASALDÁlIGA, Dom Pedro. Me Llamarán Subversivo. Salamanca: Lóngues Ediciones: 1988 edition, 1972.

CHATTERJEE, Bankimcandra. Anandamath or the Sacred Brotherhood. Translated in English by Lipner, Julius. Oxford: Oxford university Press, 1822.

Modern Modes of Power and the Peasantry. In: GUHA, Ranajit (Ed.). Subaltern Studies Vol. II: writings on South Asian History and Society. Delhi: Oxford University Press, 1983. p. 311-349.

DALEY, Janet. The Tories must make the case for capitalism. The Sunday Telegraph, Austrália, Sept., 2010. p. 24.

DASGUPTA, Swapan. Adivasi Politics in Midnapur, c. 1760 - 1924.In: Subaltern

Studies Vol. IV: writings on South Asian History and Society. Delhi: Oxford University Press, 1985. p. 101-135.

DIARIO Mar de Ajo. [S.I.: s. n.], 2004. Pedro Casaldáliga, Obispo y Poeta. Dispo, Available in: $\quad:<$ http://www.diariomardeajo.com.ar/pedro_ casaldaliga.htm>. Accessed on: 20 jul. 2013.

ESCRIBANO, Francesc. Descalzo sobre la tierra roja: vida del obispo Pere Casaldáliga. Barcelona: Ediciones Península, 2002.

FEBVRE, Lucien; MARTIN, Henri-Jean. L'Apparition, Paris: Albin Michel, 1958.

FERREIRA, Maria Almeida Candida. Só a Antropofagia nos Une', Daniel Mato(ed). In: MATO, Daniel. Estudios y Otras Practicas Intelectuales Latinoamericanas en Cultura y Poder. Caracas, Venezuela: Consejo Latinoamericano de Ciencias Sociales, 2002b.
Tornar-se outro: o topos canibal na literatura brasileira. São Paulo: Annablume, 2002a. FORBES. The World's Billionaires, New York City, 2013. Available in:<http://www.forbes.com/ billionaires/list/>. Accessed on: 1 aug. 2013.

FREYRE, Gilberto. Casa Grande e Senzala: formação da família brasileira sob o regime de economia patriarcal. Rio de Janeiro: Maia and Schmidt, 1933. Pafinations are from the English edition.

GELLNER, Ernest. Thought and Change. London: Weidenfeld and Nicholson, 1964.

GOVERNMENT INEQUALITIES OFFICE. An Anatomy of Economic Inequality in the UK: Report of the National Inequality Panel. London: London School of Economics and Political Science, 2010a.

Budget Speech. London, 2012b. Available in:<http://www.hm-treasury.gov.uk/junebudget speech.htm>. Accessed on: 23 jul. 2013.

GRAMSCI, Antonio. Selections from from the pison Notebooks. London: Lawrence and Wishart, 1971.

GUHA, Ranajit. elementary aspects of peasant insurgency in colonial India. Delhi: Oxford University Press, 1983.

Ranajit. On some aspects of the historiography of colonial India. In: GUHA, Ranajit (Ed) Subaltern Studies Vol 1: Writings on South Asian History and Society. Delhi: Oxford University Press, 1982. p. 1-8.

GUTIÉRREZ, Gustavo. Liberation, Theology, and Proclamation. In: GEFFRÉ, Claude; GUTIERREZ, Gustavo (Eds.) Mystical and Political Dimensions of the Christian Faith. New York: Herder \& Herder, 1974. p. 57-77.

Teología de la liberación, perspectivas, Lima: Centro de Estudios y Publicaciones, 1971. English edition published in 1973 as A Theology of Liberation: History, Politics, and Salvation, Maryknoll. New York: Orbis Books. Paginations are from the English edition. 1971.

The Power of the Poor in History Maryknoll. New York: Orbis, 1983.

HARDIMAN, David. The Bhils and Sahukars of Eastern Gujarat. In GUHA, Ranajit (Ed.). Subaltern Studies Vol 5: Writings on South Asian History and Society. Delhi: Oxford University Press, 1987. p. 1-55. 
INSTITUTE FOR FISCAL STUDIES. Poverty and Inequality in UK: 2010. London, 2010a.

.The distributional effect of tax and benefit reforms to be introduced between June 2010 and April 2014: a revised assessment. London, 2010. IFS Briefing Note BN108.

INSTITUTO BRASILEIRO DE GEOGRAFIA E ESTATÍSTICA. Síntese de Indicadores Sociais: Uma Análise das Condições de Vida da População Brasileira. Estudos e Pesquisas, Rio de Janeiro, v. 29, 2012.

ISLAM, Gazi. Can the subaltern eat? Anthropophagic culture as a Brazilian lens on post-colonial theory. Organization, Online, 2011. Available in:<http://org.sagepub.com/content/ early/2011/11/17/1350508411429396>. Accessed on: 15 apr. 2013.

KAUTSKY, Karl. (1935) Aus der Frühzeit des Marxismus: Engels Briefwechsel mit Kautsky Herausgegeben und erläutert von Karl Kautsky. Prague: Orbis Verlag, 1935. Available in: <http:// www.marxists.org/archive/marx/works/1882/ letters/82_02_07.htm>. Accessed on: 19. jul. 2013.

KEE, Alistair. Marx and the Failure of the Liberation Theology. Norwich: SCM Press, 1990.

LUCAS JR., Robert. The Industrial Revolution: Past and Future. In: THE FEDERAL BANK OF MINNEAPOLIS, 2003 Annual Report Essay, Minneapolis, MN, 2003. The Region. Available in: <http://www.minneapolisfed.org/publications papers/pub_display.cfm?id=3333>. Accessed on: $2 \overline{3}$ jul. 2013.

MAIA, Pedro Américo. João Bosco Penido Burnier: Mártir pela Justiça. São Paulo: Editora Loyola, 1981.

MCGOVERN, Arthur. Latin America and 'Dependency' Theory. In: NOVAK, Novak (Ed.). Liberation Theology and the Liberal Society. Washington, DC: American Enterprise Institute, 1987. p. 106-132.

Liberation Theology and Its Critics Maryknoll. New York: Orbis, 1989.

MONIBIOT, George. Upper class interests must be protected: all else can burn, The Guardian Comment, Lodon, p. 26, oct. 2013.

NAIRN, Tom. Break-Up of Britain. London: New Left Books, 1977.
POPE PAUL VI. Populorum Progressium: Encyclical of Pope Paul VI on the Development of Peoples. Acta Apostolicae Sedis, Roma, v. 59, p. 257-99, 1967. Available in:<http://www.vatican.va/holy_father/paul_ vi/encyclicals/documents/hf_p vi_enc_26031967_ populorum_en.html>.Accessed on: 20 jul. 2013.

PRASAD, Monica et al. The Undeserving Rich: Moral Values - White Working Class. Sociological Forum, Hoboken, NJ, v. 24, n. 2, p. 225-253, 2009.

RATZINGER, Cardinal Joseph (2004). Preliminary Notes on Liberation Theology. [S. I.: s. n.], 2004. Available in: <http://www.christendom-awake.org/ pages/ratzinger/liberationtheol.htm>. Accessed on: 21 jul. 2013.

RIBEIRO, Darcy. O povo brasileiro: a formação e o sentido do Brasil. São Paulo: Companhia das Letras, 1995.

ROCHA, Zildo Helder. O Dom: uma vida que marcou os rumos da Igreja no Brasil. São Paulo: Editora Vozes, 2000.

SAHA, Suranjit Kumar. Brasil e Índia: uma relação especial. Cadernos do Desenvolvimento do Centro Internacional Celso Furtado, Rio de Janeiro, v. 11, n. 11, p. 161-195, 2012.

Especialização flexível no contexto da economia de mercado globalizada: opções de políticas para Brasil e Índia. Revista APNEC, Belo Horizonte, v. 25, n. 2, p.63-90, 1997.

SARKAR, Tanika. Jitu Santal's Movement in Malda 1924-1932: a Study in Tribal Protest. In:

Subaltern Studies Vol. IV: Writings on South Asian History and Society. Delhi: Oxford University Press, 1985. p. 136-164.

SCRUTON, Paul et al. What are you worth and what you get. Guardian, Lodon, 2010. Available in:<http://www. guardian.co.uk/uk/interactive/2010/jan/26/hills-reportuk-inequality-social-trends1>. Accessed on: 25 jul. 2013.

SECOND CONFERENCE OF LATIN AMERICAN BISHOPS. Final Document. Medellín, 1968.

STIGLITZ, Joseph. The Price of Inequality. London: Penguin Books, 2013.

TAGORE, Rabindranath (1910b). Opomanito. In: SANCHAYITA, Kolkata. Visva Bharati Granthan. Vibhag: 1994 edition, 1910b. p. 509.

THE ECONOMIST. For richer, for poorer. [S. I.], v. 405 , n. 8806 , p. $13-14$, oct. 2012b. Special Report on World Economy. 
Spare a dime?: a special report on the rich. [S. I.], v. 391, n. 8625, p. 1-26, 2009b.

The few: a special report on global leaders. [S. I.], v. 398, n. 8727, pp. 1-20, jan. 2011b.

The rich and the rest. [S. I.], v. 398, n. 8727, p. 11-1222, jan. 2011a.

The rich under attack. [S. I.], v. 391, n. 8625, p. 11, apr. 2009a.

True Progressivism. [S. I.], v. 405, n. 8806, p. $13-14$, oct. $2012 a$.

TREANOR, Jill. Lloyds forced to admit scale of millionaire staff. The Guardian Financial, Lodon, p. 24, feb. 2011.

VIDAL, José Manuel. Entrevista a Pedro Casaldáliga. [S. I.: s. n.], 2006. Available in:<http:// www.redescristianas.net/2006/04/05/entrevista-apedro-casaldaliga-jose-manuel-vidal/>. Accessed on: 20 jul. 2013.

WILKINSON, Richard; PICKETT, Kate. The Spirit Level: Why Equality is Better for Everyone. London: Penguin, 2009.

WILSON, H. H. The Vishnu Purana translated from the original Sanskrit and illustrated by notes derived chiefly from the other Puranas. London: John Murray, 1840.

\section{NOTAS}

1 Tradução: Todos nós, brasileiros, somos carne da carne daquelos pretos e índios supliciados. Todos nós brasileiros somos, por igual, a mão possessa que os supliciou. A doçura mais terna e a crueldade mais atroz aqui se conjugaram para fazer de nós a gente sentida e sofrida que somos e a gente insensíevel e brutal, que também somos. Descendentes de escravos e de senhores de escravos seremos sempre servos da malignidade destilada e instalada em nós, tanto pelo sentimento da dor intencionalmente prodizida para doer mais, quanto pelo exercício da brutalidade sobre homens, sobre mulheres, sobre crianças xonvertidas em pasto de nossa fúria. ... A mais terrível de nossas herenças é esta de levar sempre conosco a cicatriz de torturador impressa na alma e pronta a explodir na brutalidade racista e classista. Ela, porém, provocando crescente indignação dará forças, amanhã, para conter os possessos e criar aqui uma sociedade solidária

2 Tradução: Ó meu triste país, Aqueles a quem você deu só humilhação.

Chegou a hora de você partilhar estas humilhações com eles.
Aqueles a quem você negou o direito de ser humano Aqueles que sempre viveram perto de você. Mas você sempre os afastou com ódio e desprezo. Chegou a hora de você partilhar estas humilhações com eles

Suranjit Kumar Saha,

Geography Political Science And Economics

Doctor em Development Studies pela University Of Wales Cardiff

Professor da Swansea University - Reino Unido

E-mail: suranjitsaha@mail.com

College Of Science- United Kingdom 102 Rhyd-y-Defaid Drive

Sketty, Swansea SA2 8AW, United Kingdom 